\title{
İnovasyon Değerinin Yaratılmasında Mimarın Rolünün Walter Gropius'un Çalışmaları Bağlamında Analizi
}

\author{
illkay KOMAN $1 *$ (i) \\ ORCID 1: 0000-0002-2195-3594 \\ ${ }^{1}$ Mimar Sinan Güzel Sanatlar Üniversitesi, Mimarlık Fakültesi, Mimarlık Bölümü, Yapı Bilgisi Ana Bilim Dalı, \\ 34427, istanbul, Türkiye. \\ *e-mail: ilkay.koman@msgsu.edu.tr
}

Öz

Tarihte insan yaşamını etkileyen yeni süreçler ve teknolojiler sadece yeni olmakla değil, var olan fikirlerin farklı bir şekilde hayata geçirilmesiyle ortaya çıkmıştır. Mühendislik tarihte çoğunlukla inşaat bilgisini yönlendiren ve yenilikleri geliştiren yegâne meslek olarak görülmüştür. Modern Hareket'in öncüleri olan mimarlar bu imajı değiştirmeye çalıştıklarında, hayatın her alanında sanayi ve makineleşmenin kabul görmesine karşılık mimarı geleneksel sanatsal statüsünden uzaklaştırmakla suçlanmıştır. Bu makale, mimarların endüstriyel inşaat yöntemlerinin geliştirilmesindeki rolünün yanı sıra, prefabrikasyon alanındaki inovatif katkılarını incelemeyi amaçlamaktadır. Bu incelemede tarama ve çapraz başvurulara dayanan tartışma yöntemi kullanılmıştır. Mimari tasarım düşüncesinin inşaat inovasyonunun ortaya çıkmasındaki etkisi, inovasyon teorileri ile mimari tasarım ve üretim düşüncesi bağlamındaki literatürün tartışılmasında Modernizmin önemli temsilcilerinden Walter Gropius'un çalışmaları örnek alınmıştır. Sonuçta mimarın rol oynadığı inovasyon süreçleri üç temel başlıkta yorumlanmıştır.

Anahtar Kelimeler: Inovasyon, yapım tarihi, prefabrikasyon

\section{Analysis of the Architect's Role in Creating Innovation Value in the Context of Walter Gropius's Works}

\begin{abstract}
Engineering has been widely accepted as the only profession that directs and develops construction knowledge. When the leading architects of the Modern Movement in Architecture tried to change this image, they were accused of distancing the architect from the traditional artistic status despite the acceptance of industry and mechanization in all areas of life. In the history of construction, important innovations, which are often associated with prefabrication, have been realized as a result of architects' design approaches that interpret function and construction together. The aim of this article is to examine the effect of architectural design thinking on the emergence of construction innovation. The literature in the context of innovation theories and architectural design and production thought was discussed through Walter Gropius, one of the important representatives of Modernism. As a result, the impact of the architect on construction innovations was evaluated and the innovation processes they contributed to were identified.
\end{abstract}

Keywords: Innovation, construction history, prefabrication

Atıf/Citation: Koman, İ. (2021). İnovasyon Değerinin Yaratılmasında Mimarın Rolünün Walter Gropius'un Çalışmaları Bağlamında Analizi. Journal of Architectural Sciences and Applications, 6 (1), 97-114. DOI: $10.30785 /$ mbud.881914 


\section{Giriş}

Tarihte insan yaşamını etkileyen yeni süreçler ve teknolojiler sadece yeni olmakla değil, var olan fikirlerin farklı bir şekilde hayata geçirilmesiyle ortaya çıkmıştır. Toplumdaki gelişmeleri de yönlendiren bu yenilikler "inovasyon" olarak nitelenir. Kökeni 16. yüzyıla dayanan inovasyon önceleri "bir eylem veya etkinlik içeren yeni bir fikir, cihaz veya yöntem" olarak tanımlanmıştır. 19. yüzyılda Gabriel Tarde, inovasyon kavramını yeniden yorumlamış, inovasyonların sosyal fenomenlerin seyrini değiştirdiğini ve insanların değişen ortamlarına uyum sağlamasına yardımcı olduğunu vurgulamıştır. Buna göre toplumda gelişmeleri yönlendiren ve onları taklit edebilenler vardır. Keşfe yol açan yenilikler ise toplumun geri kalanının takip etmesi için yeni bir çağ açar (Kinnunen, 1996). 20. Yüzyılda inovasyon araştırmaları çeşitli alanlarda sürerken, devletler inovasyonu ekonomik verimliliği artırmak için entelektüel bir meta olarak kabul etmiştir (Meyrick, 2016). Bugünkü kabulü ile inovasyon sosyal, kültürel ve yönetimsel alanlarda değişen koşullara uygun yenilikleri ve bunların tanıtımını kapsar. Yapılı çevrenin inşası insanlık tarihinde değişen ve çeşitlenen ihtiyaçlar ile teknolojideki gelişmelerin etkisi ile yeniliğe açık bir üretim alanı olarak yer alır. Sanayi Devrimi'nden bugüne, sanayileşmiş inşaat paradigması seri üretimden başlayarak, yapım seti, yapım sistemi, standartlaşma, modülerlik ve ön üretim gibi değerleri kazanmıştır. Bunların hepsi inovasyon olarak kabul edilerek, "prefabrikasyon" kavramı ile özdeşleştirilmiştir. Tasarım, çizim, imalat ve son montaj süreçleri ile koordine edilen yapı üretimi süreçleri prefabrikasyon olarak tanımlanır.

1800 'lerin ortalarından itibaren, tanıdık malzemelerin ortadan kalkması ve kullanılmaz olması inşaat sektörünün müşteri taleplerini karşılayacak yeni uygulamalara yönelmesini gerektirdi. Henry Ford'un seri üretim kavramını geliştirdiği 1910'lar bir dönüm noktasıydı. Bileşenlerin standartlaştırıımasına ve üretim süreçlerinin sistemleştirilmesine dayanan üretim yaklaşımı, kısa sürede tüm sektörlere hızla nüfuz etti. Mimarlık ve inşaat alanı da bu sistemden etkilenen sektörlerden biriydi. Özellikle Fordizm'den sonra değişen ekonomik görüşler, işverenlerin veya müşterilerin değişen ihtiyaçları ve uluslararası rekabet ortamı inşaat sektöründeki inovasyonları tetiklemiştir (Miozzo ve Dewick, 2004).

Mimarlıkta endüstrileşmiş imalat tekniklerinin benimsenmesi diğer üretim sektörlerine göre yavaş olmuştur. 19. Yüzyılın ortalarından sonlarına kadar endüstrileşmiş inşaat teknikleri köprüler, tren istasyonları ve diğer altyapı tesislerinde kullanılmıştır. Yirminci Yüzyıl başlarında ise bu teknikler konut üretim sistemlerine uyarlanmıştır (Rupnik, 2012). Aladdin Evleri (1906), Sears Evleri (1930) ve Lustron Evleri (1948) gibi örnekler mimarların katılımını göz ardı eden diğer disiplinler tarafından ticari bakış açısı ile geliştirilmiştir. Piroozfar ve Farr (2013) Yirminci yüzyılda mimari teori ve pratiğin oluşturulması sürecinde önemli bir rol oynayan teknolojinin, inşaat yöntemlerinin gelişimine ve bunların mimarlık ile ilişkisine vurgu yapmaktadır. Yazarlar Mumford (1930)'a atıf yaparak mimaride estetiğin imalat sektöründeki teknolojik gelişmelerin etkisi ile önemini yitirmeye başlamasını 1930'a tarihlemektedir. Çoğu mimarın teknolojiyi koşulsuz olarak benimsediği, gerçekleşen bu dönüşümün doğasını anlamaya çaba göstermediği ve mimari tasarım ile arasındaki bağlam üzerine düşünmediği görüşünün ortaya çıkışında ise, II. Dünya Savaşı'ndan sonra, yıkılan Avrupa'nın yeniden inşası için seri üretim ile desteklenen konut pazarının etkisi vardır. İnşaat endüstrisinde olanlar bu anlamda teknolojiden ilham alan üretim endüstrisinden farklılık gösterir. Öte yandan özellikle Modernizm ile öncü mimarlar teknoloji ve sanayileşmeyi keşfetmek için kendi yollarını aramış, teknoloji ve sanayileşmeyi tasarımları ile yorumlamıştır. Walter Gropius, Le Corbusier, Konrad Wachsmann, Frank Lloyd Wright ve Richard Buckminster Fuller gibi öncüler teknolojideki ve toplumsal yaşamdaki hızlı değişimi kavrayan, geleceği öngören, zamanlarının ötesinde düşünce yapısına sahip kişiliklerdir (Alvis, 2017).

\section{Amaç ve Yöntem}

Inovasyon literatüründe yapım, mimarlık ve tasarım anahtar kelimelerinin yer aldığı çalışmalar çok geniştir. Xue, Zhang, Yang ve Dai, (2014)'nin literatür araştırmasına göre yapım ve inşaat alanında inovasyonla ilgili literatür dört ana kulvarda devam etmektedir. Bunlar; (1) inovasyon, (2) inovasyon girdileri, (3) inovasyon sürecinin itici güçleri ve (4) inovasyon çıktılarıdır (Xue ve diğerleri, 2014). Literatürde proje paydaşlarının inovasyondaki rolünü ve benimseme davranışını içeren çalışmalar mevcut olmasına rağmen prefabrikasyon tarihi ve inovasyon arasındaki bağlantıları inceleyen çok az 
sayıda makale bulunmaktadır. Bunun nedenlerinden biri, prefabrikasyonun daha çok bir mühendislik sorunu olarak görülmesi olabilir. Buna dayanarak bu makalede, prefabrikasyon teknolojisindeki inovasyonlara mimarın katkısının incelenmesi hedeflenmiştir. Mimaride prefabrikasyon tarihindeki somut olaylar ile inovasyon kavramı arasındaki bağlamın oluşturulmasında tarama ve tartışma yöntemi kullanıımıştır. Seçilen olayların tek bir mimarın çalışmalarını içermesi tercih edilmiş, böylece tasarım deneyimindeki gelişimsel sürecin inovasyonla ilişkisinin kurulması da amaçlanmıştır. Bu bağlamda, mimaride Modern Hareketin en başta gelen aktörlerinden biri olan Walter Gropius'un (1883-1969) çalışmaları incelenmiştir. Bauhaus'un kurucusu Gropius, çağdaş mimarlık, endüstriyel tasarım, sanat eğitimi, sanatların karşılıklı ilişkisi veya endüstriyel bir çağda sanatın sosyal temelleri hakkında tartışmalar söz konusu olduğunda, her zaman gündemde olan bir mimardır. Çalışmada Gropius'un endüstriyel inşaat yöntemlerinin geliştirilmesindeki katkısının yanı sıra, teknoloji ve sanayileşme kavramları üzerine fikirleri, özellikle prefabrike konut üretimine yenilikçi katkıları; teknoloji, inovasyon, tasarım, yapım ve mimari arasındaki ilişkileri ele alan geniş bir literatüre ve çapraz başvurulara dayanan analiz ile aktarılmaktadır.

Makale sonucunda mimarın rol oynadığı inovasyon süreçleri tanımlanmış ve mimarın inovasyon değeri oluşturmadaki rolü değerlendirilmiştir. Bilimsel literatürde büyük çoğunlukla teknik bir mühendislik konusu olarak yer alan prefabrikasyonun, mimarlık ve mimari tasarım bakış açısından aktarılması ve genellikle teknoloji bağlamında incelenmiş olan inovasyon kavramının, mimaride tasarım düşüncesi ile ilişkilendirilerek yorumlanmasının literatüre yeni bir katkı sağlayacağı düşünülmektedir.

\section{Bulgular}

\subsection{Walter Gropius'un Tasarım ve Uygulamalarında İnovasyon}

Günümüzde inovasyonun bilimsel ve teknik literatürde, tarih, sosyoloji, yönetim, ekonomi gibi sosyal bilimlerde, beşerî bilimler ve sanatta tartışıldığına dikkat çeken Godin (2008) toplumda çoğunlukla teknolojik yenilik olarak algılandığını, oysa etimolojik ve tarihsel olarak kavramın çok daha geniş bir anlam içerdiğini savunur. Godin (2008)'e göre günümüzde inovasyon, modern toplumun amblemi, pek çok sorunu çözmek için her derde deva ve üzerinde çalışılması gereken bir olgu haline gelmiştir. Bu geniş tartışma alanında inovasyon kavramının tanımı üzerine pek çok araştırma yer bulur. Alandaki ilk araştırmacılarda Ogburn (1941) inovasyonu "çevreyi derinden dönüştürmeye hizmet eden icatlar" olarak tanımlamıştır. Kamien ve Schwartz (1982) ve Rogers (1983) ise inovasyonu kullanıcı veya benimseyenin kabulü ve davranışları açısından yorumlar. Buna göre; inovasyon kullanıııların yararlanma ve kullanma şekline bağlı olarak süreç veya ürün" veya "benimseyen tarafından yeni olarak algılanan bir fikir, prosedür veya nesne" olarak ortaya çıkar. Ayrıca geçmişten gelen bir fikrin veya buluşun yeniden yorumlanarak yeni kullanıcılara sunulması ile de yenilikçi bir değer yaratılır. Dosi (1988)'ye göre ise bir tasarım, ürün, sistem veya süreç için araştırma, geliştirme ve keşiflerin ticarileştirilmesi ile inovasyon gerçekleşir. Abrahamson (1996) ve Freeman ve Soete (1997) inovasyonda teknolojinin baş aktör olmasının gerekmediğine vurgu yapar. Uygulanan bir tekniğin yeni olabilmesi için mevcuttaki tekniklerden ayırt edilebilir ölçüde farklı olması yeterlidir. Ayrıca "bir süreç, ürün veya sistem içerisinde uygulayıcılar için yeni ve önemli olan bir değişim veya gelişimi hayata geçirmek" de inovasyon olarak kabul edilir. Kişiler veya kurumların ortaya çıkardıkları değeri "yeni ve önemli bir gelişim veya buluş" olarak nitelendirmiş olmaları da gerekir. Oslo Rehberi'nde ise inovasyon "yeni veya önemli ölçüde geliştirilmiş bir ürün veya süreç, yeni bir pazarlama yöntemi veya işletmelerde yeni bir örgütsel yöntemin gerçekleştirilmesi" şeklinde tanımlanmıştır (OECD, 2005).

Literatürde inovasyonun buluştan farkını savunan görüşler bulunur. Schumpeter (1939)'e göre, inovasyon nitelik olarak buluştan farklıdır. Her buluş inovasyonu teşvik etmez. Buluş, entelektüel bir yaratıcılık eylemidir ve ekonomik önemi yoktur. İnovasyon ise ekonomik bir karardır ve "kalkınma için itici güç" olarak tanımlanarak, birçok bileşeni olan karmaşık bir kavram olduğundan hem bir süreç yenilemesini hem de bir sonucu kapsar. Godin (2008), tarihte önceleri hayal gücüyle ortaya çıkan buluşların, daha sonra edebiyat ve Şekil sanatlarda, mimari, denizcilik, metalürji ve askeri zanaatta giderek artan bir şekilde teknolojiden kaynaklandığına vurgu yapar. On dördüncü ve on beşinci 
yüzyılın sonlarından itibaren patent yasaları aracılığıyla teknolojik buluşun kurumsallaştırılması sağlanmıştır. Teknolojik buluşları karakterize eden üç norm vardır: özgünlük, köken veya önceliğe göre özgünlük ve fayda (Godin, 2008). Brookes ve Poole (2012) ise buluşun "özgün bir fikir yaratma veya keşfetme süreci", inovasyonun ise "bir fikrin kullanılması ve bilinçli bir şekilde uygulanması" olduğunu savunur.

Inovasyonun oldukça geniş bir terminolojiye sahip olması, ilgili literatürün geniş bir alanı kapsamasından kaynaklanır. Bu makalede inovasyon terminolojisi "inovasyon" ve "teknolojik inovasyon" olmak üzere iki temel alt başıkta ve üç kategoride sınıflandırılmaktadır. Buna göre kaynak, eylem ve etkileri bağlamındaki terminoloji Çizelge 1'de gösterilmektedir. Makalede, tasarımcı kimliği ile mimarın inovasyon değeri oluşturmadaki katkısı Walter Gropius örneğinde bu terminoloji bağlamında tartışılacaktır.

Çizelge 1. İnovasyon ve teknolojik inovasyonla ilişkili terminoloji (Godin, 2008)

\begin{tabular}{|c|c|c|}
\hline $\begin{array}{l}\text { Inovasyon } \\
\text { Terminolojisi Kategorisi }\end{array}$ & İnovasyonla ilişkili terminoloji & $\begin{array}{l}\text { Teknolojik İnovasyonla ilişkili } \\
\text { terminoloji }\end{array}$ \\
\hline Kaynak & \multicolumn{2}{|c|}{ İlham, Yaratıcılık, Merak, Hayal gücü, Mantık, Özgünlük, Özgürlük, İfade, İrade, Seçim } \\
\hline Eylem & $\begin{array}{l}\text { Taklit, İcat, Keşif, Deney, Araştırma, } \\
\text { Girişim, Değişiklik, Yaratıcılık, Üretim, } \\
\text { Yenilik, İnşaat-Imalat, Ürün-Süreç, } \\
\text { Yöntem, Fabrikasyon-Yapım, Uygulama }\end{array}$ & $\begin{array}{l}\text { Taklit, Sanat-Zanaat, Proje, Makine, } \\
\text { Araç-Alet, Cihaz-Motor, Teknik, } \\
\text { Teknoloji, Otomasyon-Mekanizasyon, } \\
\text { Sermaye-Ekipman }\end{array}$ \\
\hline Etkiler & $\begin{array}{l}\text { Kültür, Medeniyet, Evrim, Modernite, } \\
\text { ilerleme, Gelişme-Ilerleme, Devrim, } \\
\text { Yenilik }\end{array}$ & $\begin{array}{l}\text { İşe yararlık-Fayda, Kullanışılık, Büyüme- } \\
\text { Üretkenlik, Verim, Rekabet gücü, } \\
\text { Liderlik, Çıkar-Ayrıcalık, Etkililik, Kalite- } \\
\text { Standart, Sağlık }\end{array}$ \\
\hline
\end{tabular}

\subsubsection{Fikir inovasyonu: endüstriyel mimarlık}

Münih'teki (1903-04) ve Berlin'deki (1905-07) teknik enstitülerde mimarlık okuduktan sonra, bir süre Berlin'de bir mimarlık ofisinde çalışan Gropius 1907 'de faydacı okulun ilk üyelerinden olan Peter Behrens'in Berlin'deki ofisine katıldı (Koeper, 2020). Gropius'un ofisteki görevi AEG fabrika projelerinde çalışmaktı. Behrens haberi ve izni olmadan bir prefabrike yapı sistemi geliştirerek ve AEG yetkililerine sunan yenilikçi genç Gropius'u işten çıkardı (Jones, 2017). Gropius daha sonra, Behrens'le yaptığı çalışmanın ilerici mimariye ile sanatın karşılıklı ilişkisine olan ömür boyu ilgisini şekillendirdiğini söyleyecekti. Gropius'un farklı bir tasarım düşüncesi ve yapı üretimi vizyonuna sahip olduğu daha kariyerinin başlarında belliydi. Tasarım düşüncesi "herhangi bir tasarımcı için temel yaratıcı süreç" olarak tanımlanır. İnovasyon ve tasarım düşüncesi arasındaki ilişki sadece teknoloji bağlamında oluşmamaktadır. Scruton (2013) estetik algı ve mimarlık deneyimi tartışmasında, fikrin deneyime dair bazı iç görülerle ortaya çıktığını vurgular. Bu mimari ürünü algılayanlar kadar, yaratanlar açısından da geçerli bir durumdur. Gropius örneğinde olduğu gibi mimari tasarım sürecinde mimarın deneyimi, hayal gücü ve yeteneği güçlü motivasyonlardır. İnovasyon yaratımında bu motivasyonlar önemli rol oynar. Yaratıcı algı mefhumu, bir fikrin doğuşunu da temsil eder (Wylant, 2008). Loureiro ise (2014) yaratıclık ve iç görü yeteneğini Brezilyalı filozof Carvalho (2017)'nun "devrimci zihniyet" tanımlaması ile ele alır. Bu düşünceye göre devrimci zihniyet, anlık sorunlara ve durumlara yanıt aramaz, dünyayı ve geleceği varsayıma dayalı senaryolara göre inşa edecek evrensel yanıtlar arar. Devrimci, bugünü geçmiş deneyimlerle karşılaştırarak yargılamak yerine, onu idealize edilmiş varsayıma dayalı gelecekle karşılaştııı. Modern insanların "yeni” yaşamları için mükemmel ortamı şekillendirdiği bir gelecek ideali başta Gropius olmak üzere Modern Mimarinin öncülerinin de gündemindeydi. Modernizm'in ilk yıllarından itibaren bu varsayıma dayalı geleceğe uyacak binalar "iyi mimari" örneği olarak kabul edildi (Loureiro, 2014).

1919 'da Gropius, Bruno Taut ve Adolf Behne, Berlin'de düzenlenen "Sanat için Çalışma Konseyi" (Arbeitsrat für Kunst) sergisinin broşürünü yazdı. Gropius metnin açılışını "döneminin mimarisinin gerçek güzellikten yoksun olduğuna inandığını ve sadece anlık ihtiyaçlara pratik bir cevap olduğunu" vurgulayarak yapar. Gropius'a göre, yirminci yüzyılın başlarındaki mimari inşa edilmiş bir güzellik dünyasına duyulan özlemi tatmin etmemektedir. Ayrıca kendi neslinin, gelecekte gelmesi beklenen 
daha mutlu bir çağla gerçekleştirilecek ateşli, cesur, ileriye dönük bir mimariyi tasarlayabileceğine inanıyordu. Gropius'un yazdığı metinden devrimci zihniyeti anlaşılmaktadır. Ütopik, ideal bir gelecek, için mevcut mimari üretim yetersiz ve anlamdan yoksundur (Loureiro, 2014). Bu zihniyetin yarattığı tasarımlarının mimari ve yapı üretiminde devrimci etki yaratmış olması tesadüf değildir. Kuşkusuz her devrimci zihniyet inovasyon yaratamaz. Devrimci zihniyet mimarın zengin yaratıcı algısı ile birleşince inşaat inovasyonlarının kaynağını oluşturabilir.

19. yüzyılın ortasından itibaren Batı Avrupa ve Ingiltere'deki zanaatkârlar, Endüstri Devrimi'nin etkisiyle fabrika yapımı ucuz ürünler ile rekabet etmenin zorluğunu deneyimlemekteydi. Öte yandan, entelektüel ve sanat çevrelerinde, sanatçılar ile zanaatkârların ekonomik hayattan soyutlanması sonucu oluşacak sorunlar da gündemdeydi. Bunun sonucu olarak Alman Sanatlar ve Zanaatlar Derneği (Deutscher Werkbund) 1907'de Almanya'da kuruldu. Dernek, "sanat, endüstri, zanaat ve ticaretin en iyi temsilcilerini seçerek, endüstriyel işlerde kaliteye yönelik mevcut tüm çabaları birleştirerek" zanaatkarlığı yüceltmeyi hedeflemekteydi. 1910'da Adolf Meyer ile bir ofis açan Gropius da ve 1911'de derneğe üye oldu. 1911'de Hagen'deki “Anıtsal Sanat ve Endüstriyel Mimari” konulu konuşmasında dikkatini endüstriyel mimariye çevirdiğini açıklayarak, 19. yüzyıl demir ve çelik yapılarındaki süslemelere karşı çıktı. Mimarlığın insanlığın sonu gelmeyen ve sürekli değişen intiyaçlarını karşılaması gereken bir meslek olduğuna vurgu yaparak, sanat ve teknolojiyi uzlaştırmanın mimarların görevi olduğunu savunuyordu. Gropius yapı üretiminde, parçaların prefabrikasyonu ve şantiyede montaj gibi yapım teknikleri ile makineleşmenin kaçınılmazlığını vurguluyordu. Diğer taraftan, bunların beraberinde getirdiği kısıtlamaları kabul ediyordu. Ancak sanatsal değerlerle donatılmış ve eğitilmiş tasarımcıların makinenin ölü tabiatına ruh kazandırma vazifesi olduğuna inanıyordu. Sanatta taklide, aşırılığa ve dogmaya karşıydı. Bir ürünün işlevinin görünümünü belirlemesi gerektiği fikrini desteklemekle birlikte, ürünlerin aşırı basitleştirmesine karşıydı (Hoffa, 1961; Röder ve Elliott, 1998; Laureiro, 2014).
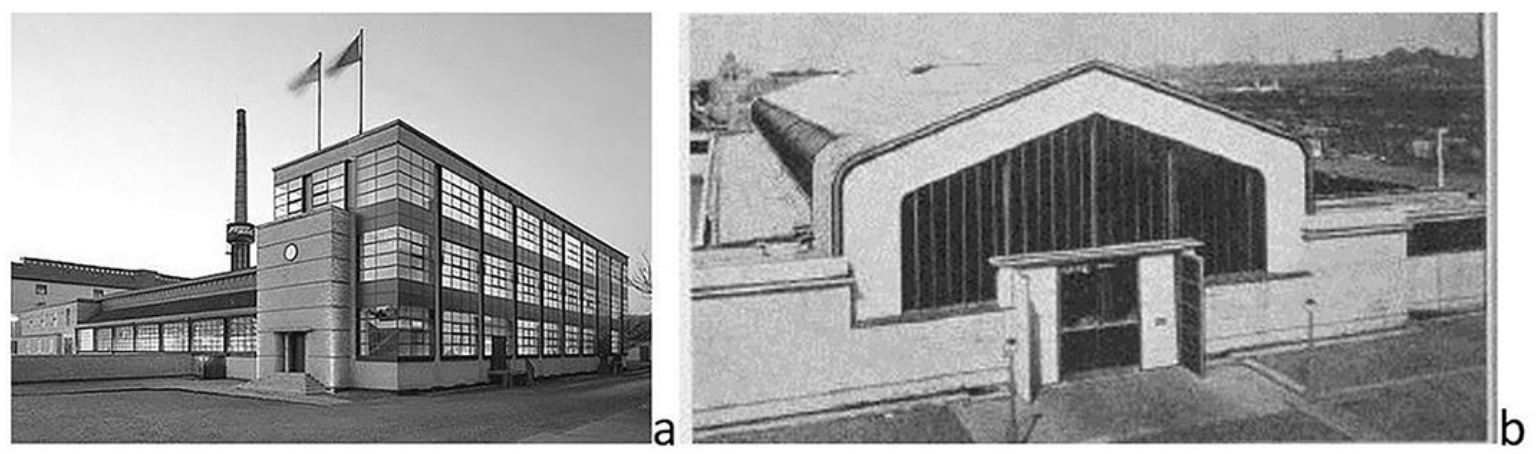

Şekil 1. a. Walter Gropius ve Adolf Meyer, Faguswerk fabrika binası (1911) (Carsten Janssen / cc-by-sa-2.0-de, 2021) b. Walter Gropius ve Adolf Meyer, Werkbund Sergisi ofis ve fabrika binaları (1914) (Bayer ve diğerleri, 1938, s.17)

Gropius, Alman Sanatlar ve Zanaatlar Derneği'ndeki liderliği sayesinde, sanatları bir toplumda tutarlı ve üretken bir güç olarak birleştirmenin gerekliliğini daha çok fark etmişti. Bu dönemde kariyerine iki önemli bina damgasını vurdu. Meyer ile ilk olarak Alfeld-an-der-Leine kentindeki Faguswerk (Şekil 1.a) ayakkabı fabrikasının cam perde cephesini tasarladılar (1911). ilk defa bu binada kullanılan köşe doğramalar sayesinde bu tasarım Avrupa modernizminin en önemli anıtlarından biri kabul edilmektedir. Cephe Gropius'un iş̧̧i sınıfı için sağlıklı fiziksel koşullar ve doğal ışık ve havalandırma sağlama kaygısının ve endüstriyel yapı üretimine olan ilgisinin bir göstergesidir. Köln'deki model ofis ve fabrika binaları (1914) (Şekil 1b) ise Werkbund Sergisi için yapılmıştır. Serginin amacı derneğin kuruluşundan itibaren geçirdiği yedi yıldaki çalışmaların bir özetini sunmaktır. Gropius bir binanın yapısal oranlarını belirlemenin mimarın en temel görevlerinden olduğunu, dekoratif süslemelerin bu anlayışın önüne geçmemesi gerektiğini savunuyordu. Ona göre modern yaşamın enerjisi ve ekonomisi, seçilen sanatsal biçimler üzerinde kesin bir etkiye sahip olmalıydı. Fagus işleri, görünür çelik desteklerle kırılan geniş cam duvar alanlarıyla özgün ve başka yapılardan etkilenilmeyen bir örnek olarak gösterilmektedir. Köln binaları ise resmi bir dile; gösterişli yalın bir nesnelliğe sahiptir (Koeper, 2020; Röder ve Elliott, 1998). 
Yenilikçi düşünce yapısı, Gropius'un 1919'da Weimar'daki Grand-Ducal Saxon Sanat ve El Sanatları Okulu'nu devralarak Bauhaus Okulu'nu kurması ile tasarım eğitimi alanındaki çalışmalarına da yön verecekti. Hoffa (1961)'ya göre Bauhaus, yıllar içinde gittikçe güçlenen uluslararası bir harekete dönüşmüştür. Uzun (2019)'a göre "Bauhaus'ta biraraya gelen avangard sanatçılar, Bauhaus"un reform hareketleri ile toplumu değiştirebilecek bir güç olmak istedi ve modern bir insan ve çevre türü oluşturmayı hedeflediler. Disiplinlerarası bir çalışma topluluğunda, "geleceğin inşası" - ve dolayısıyla geleceğin kendisi - tasarlanmalı ve yaratılmalıydı". Bu nedenle Bauhaus'un başında olan Gropius bir mimar endüstriyel tasarımcı ve toplum planlamacısı olarak ününü hak etmiştir. Carvalho (2007)'ye göre "Teknolojinin toplum üzerindeki etkisi artarken, kültürün her şeyi teknoloji kategorisi altında yorumlama eğilimi vardır. Teknolojik eylemin dışında kalan her şey de hayal gücünün dışında kalır." Bu nedenle Gropius örneğinde olduğu gibi, inovasyon değeri yaratmakta öncülük eden mimarlar sadece teknolojik ürünleri veya cihazları kullanmakla yetinmeyip, aynı zamanda yapılı çevreyi bir "teknolojik mantık" da dahil ederek tasarlama eğilimindedir. Böylece toplumu değiştirmeyi de amaçlarlar (Loureiro, 2014). Örneğin Gropius'a göre çığır açan endüstri mimarlığı anlayışında, mimarlar prototipler tasarlamak yerine, yapı endüstrisinin kendisini tasarlamalıydı. Bauhaus, bu yeni anlayışı temsil eden bir okuldu. Özellikle seri üretime yönelik modelleri geliştiren bir laboratuvardı. Gropius, inşaatın sahadan uzakta fabrika koşullarında yapılacağı tek bir organize endüstrinin geliştirilmesi çağrısında bulunmuştu. Buna göre mimar, konutu bir tüketici ürünü olarak görmeli ve tamamen saha dışı çağdaş endüstri üretime dayanan bina ticareti kavramına uygun fikirleri geliştirmeliydi (Rupnik, 2012).

\subsubsection{Sistem ve süreç inovasyonu: konut sistemleri üzerine fikirler}

Savaş sonrasında 1921 'den itibaren ilgisini Amerika'da gelişen teknoloji ve endüstriye çeviren Gropius 1922'de, yayınlanmamış bir el yazmasında "konut makineleri" (Wohnmaschinen) fikri üzerinde durmuştu. Toplumun her ferdinin bir evi olması idealine ulaşmada gelişen makineleşmenin konut makineleri fikrini uygulamak için bir fırsat yarattığını düşünüyordu. Sanayileşmede Almanya'nın Amerika'nın çok gerisinde kaldığını düşünüyordu. Ford'un montaj hattından ilham alarak çok sayıda konut üretimi için yapım seti kurma fikri üzerinde çalışıyordu. Geçmişi Otto ve Gustav Lilienthal'ın 1870 'lerde icat ettiği Anker yapı oyun setine dayanan yapım seti fikri 19. yüzyılın ortalarından itibaren mimaride uygulanmaktaydı. Gropius'a göre yapım setleri hassasiyet ve değiştirilebilirlik özelliklerine sahip olmalıydı. Bu özellik teknoloji tarihinde tek tek öğelerin daha büyük bir birlik oluşturma yeteneğini, yani öğelerin esnek bir şekilde bir araya getirilmesi ve bir bütün halinde konfigürasyonunu tanımlayan "totipotent" kavramı ile özdeşleşmiştir. Gropius tarafından yeniden yorumlanan bu yaklaşım izleyen yıllarda diğer mimarlar tarafından da benimsenmiştir. Gropius, bu yaklaşımları bir dizi deneysel konut projelerinde uygulamıştır. Bunlardan ilk ikisi 1923'teki büyük Bauhaus sergisinde sergilenen "Petek yapı" (Wabenbau) konutu (1922) (Şekil 2.a) ve "Tip serisi" (Typenserienhaus) konutudur (1923) (Şekil 2.b). Petek yapı projesinde meslektaşı Fred Forbát'a standartlaştırılmış, değişken evler yapmak için çalışma talimatı vermişti. Standartlaştırımış beton oda üniteleri kullanma fikrine dayanan Petek yapı sistemi projesinde Gropius'un imzası yer almamıştır (Seelow, 2018; Jönsson, 2013).
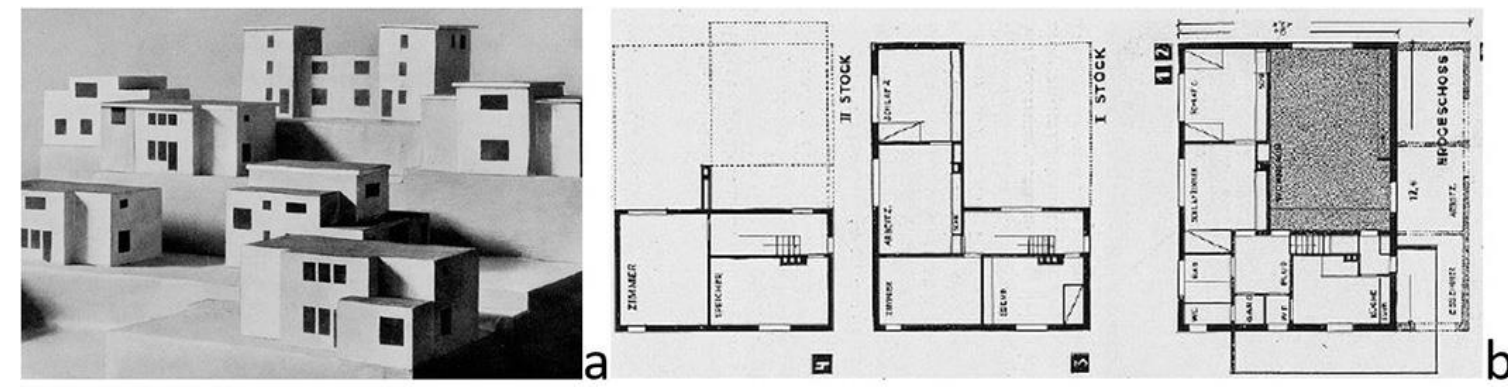

Şekil 2. a. Walter Gropius ve Fred Forbát, Petek yapı ev sistemi, 1922, b. Walter Gropius, Tip serisi ev sistemi, 1923 (Nierendorf, 1923, s.169-170)

Gropius'un prefabrikasyona ilişkin yenilikçi fikirlerini inşa sürecine çevirmek ise kuşkusuz hayal edildiği kadar basit değildi. Yirminci Yüzyılda Gropius gibi çok az sayıda mimar yaratıcı çalışmalarla prefabrikasyona yenilikçi katkılar sağlayabildi. Bu katkıları sağlamak için sistem düşüncesi yetkinliğinin 
mimarda bulunması gereklidir. Sistem düşüncesi, indirgemeciliğe ve analitik düşünceye bir tepki olarak Yirminci Yüzyıl'da ortaya çıkmıştır. Bu düşünce, doğrusal neden ve sonuç ilişkilerinden ziyade ağların geniş ölçekli dinamiklerine odaklanır. Mimari tasarımın inşa edilmesi için çok sayıda yolun olduğunu kabul etmek gereklidir. Tasarım uygulamalarını, inşaat sözleşmelerini, malzemeleri, montaj süreçlerini, uygulama şekillerini ve kullanım süreçlerini organize etmek için farklı yollar sistem düşüncesi yaklaşımı ile araştırıır. İnovasyon yaratımında sistem düşüncesi, bir bina sistemini neyin oluşturduğuna dair geniş bir anlayış gerektirir. Mimari tasarıma dayalı inşaat eylemi niteliksel ve niceliksel bilginin bir ürünü olmayıp, proje karmaşıklığı ve sosyal ajanların çok ve farklı oluşu nedeniyle kolayca ölçülemeyen ve değişken bir sistemdir. İnşaatta karmaşıklık sistemin yönetilemez olmasına neden olacak düzeye erişmemelidir. Bu nedenle, meslek pratiğinde ve uygulamada sistem düşüncesi, sistemin kapsamını, parçalarını, bağlantıları ve ağları belirlemek üzere geniş bir sorgulama yaklaşımı içerir. Böylece ortaya çıkan çözümler sistem işlevi, ölçek, kapsam, hiyerarşi, girdiler, çıktılar ve öğeler arasındaki dinamik denge dereceleri, bozulma gibi soruları da yanıtlar. Bu nedenle, Gropius gibi yenilikçi mimarlar bir binanın yapı sistemlerini tasarlayıp belirlerken, eş zamanlı olarak kültürel, ekonomik, ekolojik ve hatta politik sistem ağlar arasında da sistematik ilişkiler kurduklarından toplumdaki birçok sistem kuruculardan biri olarak kabul edilirler (Moe ve Smith, 2012).

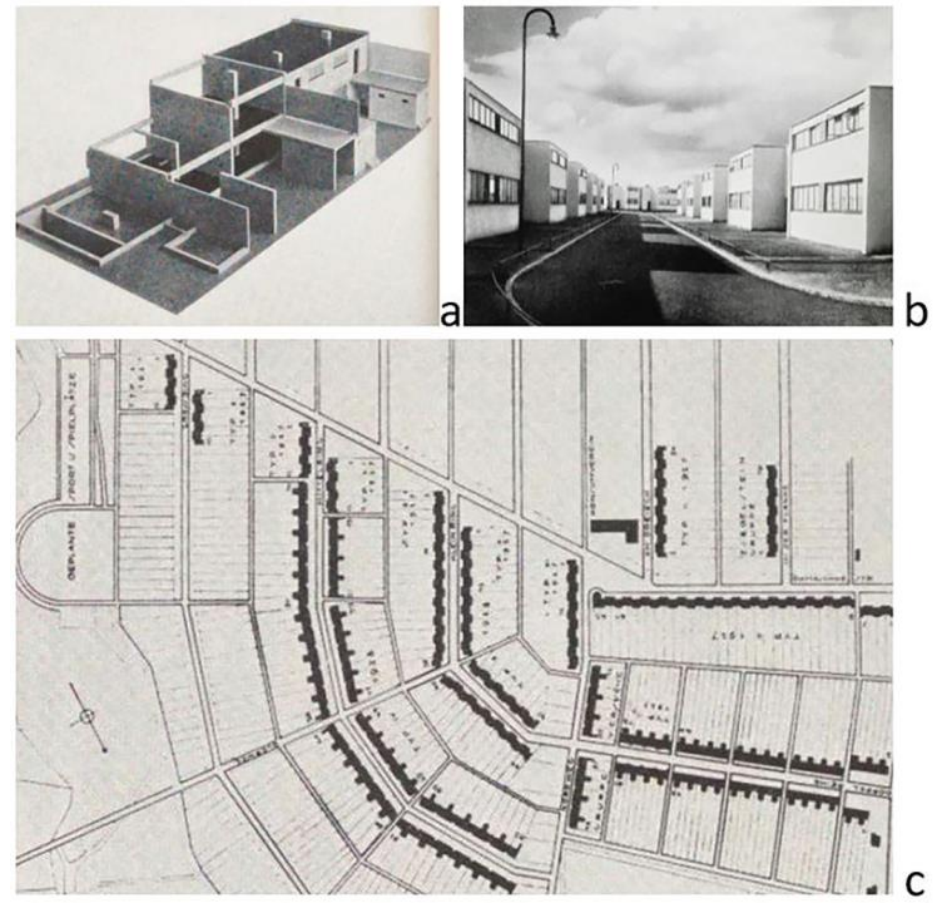

Şekil 3. Walter Gropius, Törten Konutları, 1926-1928, a. Sistem perspektifi, b. Genel görünüm, c. Vaziyet planı (Bayer vd., 1938, s.110-111; Gropius, 1930, s.161)

Gropius bu rolü Birinci Dünya Savaşı'ndan sonra Avrupa'da kentsel nüfus için yeni konut alanları inşa edilmesi ihtiyacının ortaya çıkması ile üstlenecektir. Almanya'da 1926'da bir konut teşvik yasası çıkarılmış, 1927'de Reich İnşaat ve Konutta Ekonomik Verimlilik Araştırma Derneği kurulmuştu. 1931'e kadar, standardizasyon ve planlama yoluyla ekonomik konut üretimi gerçekleştirilen çok sayıda konut yerleşkelerine teşvik veren dernekte Gropius da yer aldı Gropius bu süreçte tasarladığı ve yönettiği Dessau'daki Törten Yerleşkesi (1926-1928) konut üretiminde bir devrim yaratan inşaat sahasının endüstriyel bir montaj hattına dönüştürüldüğü planlama modeli ile öne çıkar. Projede büyük ölçekli ve fabrikada üretime dayalı prefabrikasyon yerine, şantiyede endüstrileşmiş küçük kapasiteli saha teknolojileri kullanma yolu tercih edilmişti. Üç farklı tipte ve altı varyasyonlu toplam 316 sıra ev üç ayrı aşamada inşa edildi (Şekil 3a-b). Gropius'un amacı maliyetleri düşürmek için teslim tarihlerindeki gecikmeleri önlemekti. Bu nedenle bütün iş süreçlerinin organizasyonunu önceden planladığı karma bir iş akış diyagramı ile yönetti. Inşaat malzemelerinin temini ve nakliyesi, inşaat teknikleri, iş planlaması, sahanın boş alanının düzenlenmesi, vinçlerin organizasyonu ve vinç operatörlerinin eğitimi bu planlamada yer aldı. İnşaat bölgesinde bol miktarda bulunan çakıl, kum ve cüruftan yararlanarak yerel kaynakları kullanma yoluna giden Gropius, kum ve çakılın agrega olarak 
kullanıldığı prekast beton elemanların sahada üretimine dayanan bir inşaat sistemini kurdu. Cüruf ise, bölme duvarlarının ve iç bölmelerin taşıyıcı duvarları için beton blokların üretiminde kullanılarak, bugünkü sürdürülebilir yapım ilkelerinden biri olan malzeme ve kaynak kullanımına uygun bir yaklaşım sergilenmiş oldu. Bloklar içi boş ve tek bir operatörün kaldırabileceği boyutlarda $(22,5 \times 25 \times 50 \mathrm{~cm})$ tasarlanmıştı. Illk kez burada uygulanan prefabrike beton elemanlar, daha sonra Ernst May'ın Yeni Frankfurt projesinde gerçekleştirdiği panel sistemine (Plattenbau) ilham oldu. Gropius'un kararları malzeme maliyetlerini düşürmüş, şantiye organizasyonu, çalışma ekiplerinin konumlanması ve malzemelerin depolanması için sahada yeterli alanlara sahip olma güçlüklerini beraberinde getirmişti. Bu sorun sıra evlerin ön ve arkalarında bahçe alanlarında merkezi bir omurga oluşturarak vaziyet planı kararları ile çözüldü (Şekil 3.c). Inş̧aat sürecince bu omurga destek duvarları, döşemeler, cephe panelleri ve çatı sisteminin montajı için her iki tarafa hizmet veren vinçler için hareket alanı olarak kullanıldı (Nerdinger, 1988; Rodríguez ve Montrabal, 2011; Seelow, 2018).

Törten projesi endüstrileşmiş yapım tekniklerinden, fabrikada prefabrikasyona geçişin başlangıç deneylerinden biri olarak kabul edilir. Projenin inovasyon değeri ise Manley (2008)'in kategorilerine göre, teknoloji ve organizasyon temeline göre inşaat inovasyonu oluşturması açısından ortaya çıkmaktadır. Projelerde organizasyon yapısındaki değişiklikler yoluyla teknik yenilikler ortaya çıkarılarak ekonomik sonuçlara dönüştürebilmektedir. Teknolojik yenilikler hem süreç hem de ürün yeniliği olarak ortaya çıkabilir (Lundvall, 2007). Tatum (1989) süreç yeniliklerinin, olağan inşaat işlemlerinin gerçekleştirilmesi veya standart bir işlemin verimliliğinin iyileştirilmesi için tasarlanan veya geliştirilen inşaat yöntemlerinde iyileştirmeler olduğu görüşündedir. Ayrıca, süreç yeniliği, ilgili girdilerle daha fazla çıktı sağlayan teknolojideki ilerlemeler olarak görülmüştür (Davis ve diğerleri, 2016). Bu sınıflandırmalar kapsamında, Törten projesinin prefabrikasyon alanında ekonomik sonuçları olan bir teknik yenilik ile süreç yeniliğini barındırdığı sonucuna varılabilir.
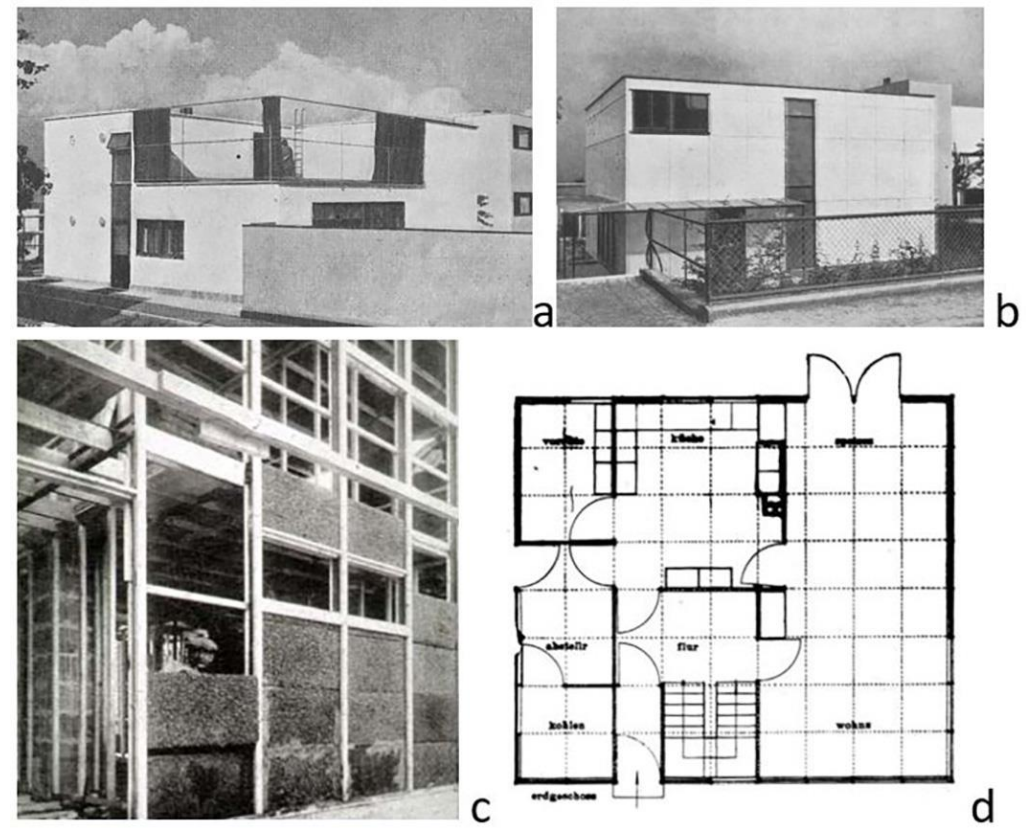

Şekil 4. Walter Gropius, Weissenhof konutları, 1927, a. 16 numaralı konut, b. 17 numaralı konut, c. Çelik iskelet ve panel dolgu inşaatı (Gropius, 1927, s. 61) d. Planda modüler ızgara düzeni

(Rodríguez ve Monrabal, 2011, s.378)

Gropius'un jenerasyonundaki Mies van der Rohe gibi öncü mimarların 1920'nin başlarında geleceğin modern Almanya'sı için yapılar tasarlama eğilimi inşaat inovasyonları için yeni laboratuvarlar olarak tanımlanabilecek projeleri de beraberinde getirmişti. Bunlardan biri olan Weissenhofsiedlung konut projesi için, Alman Sanatlar ve Zanaatlar Derneği'nin organizasyonu ile Ludwig Mies van der Rohe'nin seçtiği ve yönettiği 17 mimarlardan oluşan bir grup görevlendirildi. Grup üyelerine göre proje 'dönemin yeni yapı sanatı' örneği olarak hayata geçirilmişti. Gropius Weissenhofsiedlung'da 16 (Şekil 4a) ve 17 (Şekil 4b) numaralı evleri tasarladı. Törten'de deneyimlediği üretim tekniklerini, süngertaşından yapı bloklar ile çelik çerçeve strüktürü birleştirerek geliştirdi (Nerdinger, 1988). 
Gropius 16 numaralı yapıda tamamen kuru inşaat tekniklerini uygulamak istese de başarılı olamamış, yapı yarı kuru inşaat teknikleri ile gerçekleştirilebilmiştir. 17 numaralı evde ise standart ticari hazır panoları kullanarak kuru inşaat teknikleri hedefine ulaşmıştır. Panoların ölçülerini referans alarak metrik bir modülasyon uygulanan yapı, modüler yapım ve tasarım alanındaki deneysel yapılardan biri olarak kayda geçti (Şekil 4d). İskelet Z profilli çelik elemanlardan oluşmaktaydı (Şekil 4.c). Cephe kaplaması olarak ise fiber çimento plakalar kullanıldı. Bu projelerde kat planı ve tüm yapı bileşen ve elemanları bir modüler ızgaraya göre planlanmıştı. Illk olarak 1802'de Jean Nicolas Louis Durand tarafından önerilen, binaların standart bir ızgaranın parametrelerine göre bölümlenmesi fikri, daha sonra geleneksel yapı malzeme ve elemanlarının konumlanmasında kullanıldı. Gropius fabrika ürünü yapı bileşenlerini kullanarak boyutsal koordinasyonu sağlayacak, bu tasarım yeniliği inşaat endüstrisinde daha önce benzeri görülmeyen, ancak makine mühendisliğinde yaygın olan bir sistemleştirme ve boyutsal doğruluğu da beraberinde getirecekti (Alvis, 2017; Seelow, 2018; Rodríguez ve Montrabal, 2011).

\subsection{3. Ürün ve organizasyon inovasyonu: modüler yapı elemanları ve yapım seti araştırmaları}

1928 tarihli "Modern Yapı Endüstrisinin Organizatörü Olarak Mimar ve Sanayiye Yönelik Talepleri" başlıklı makalesinde Gropius, rasyonelleştirme çabaları ve deneyimi sonucunda konut üretimindeki üç seçeneğe vurgu yaptı. Birincisi "geleneksel, tamamen zanaatkarlığa benzeyen inşaat tarzı", ikincisi "seri üretim ve montaj hattına dayalı özdeş konut inşaatı", üçüncüsü ise "esnek yapım seti sistemi ile konut üretimidir". Gropius kuru inşaat tekniklerine dayanan açık ve modüler yapı elemanlarından oluşan esnek yapım sistemleri geliştirmeye odaklanmıştı. Günümüzde de inşaatta inovasyon, farkı karmaşıkık derecelerine sahip esnek bina bileşenleri kullanılarak, binaların ve mimari tasarımın benzersiz bir sistem yaklaşımıyla gerçekleştirilmesi ile sağlanabilmektedir. Gropius geleneksel malzemelerle mimariyi yeniden icat etmekle ilgilenmemiş, endüstriyel olarak üretilmiş malzeme ve mekanizmalar yardımı ile üretilecek mimari fikrine odaklanmıştı. Bu kapsamda hafif panellerin performanslarının iyileştirilmesi, esnek ve hafif duvarların üretilmesi, iyileştirilmiş cephe, pencere ve kapı mekanizmaları, mekanik havalandırma mekanizmaları gibi inşaat endüstrisine yönelik taleplerini sık sık vurgulamıştı (Seelow, 2018; Smith ve Quale, 2017).

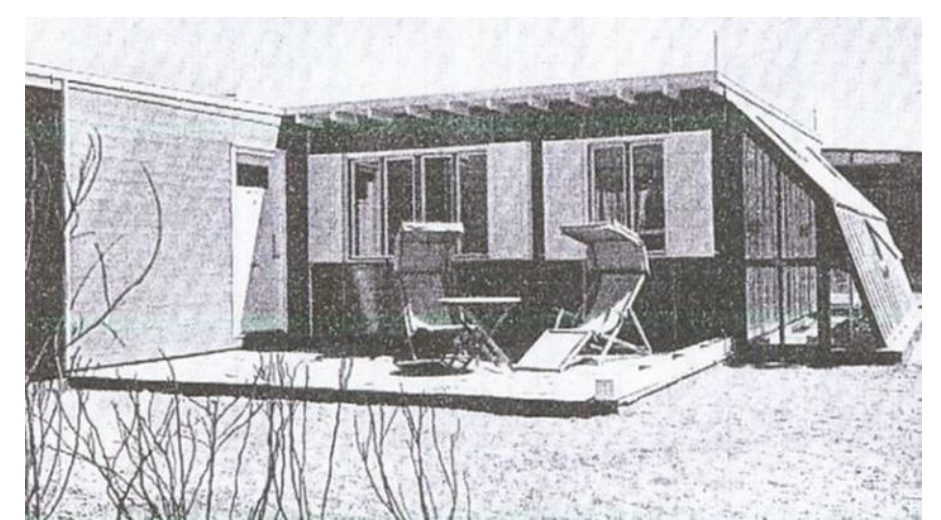

Şekil 5. Walter Gropius, Bakır evler, Güneş, Hava ve Herkes İçin Ev Sergisi, 1932, Büyüyen ev, tip L-1 (Anlage Katalog Kupferhäuser)

Gropius'un konut üretim araştırmaları 1920'lerde bakır ve pirinç endüstrisinde küresel bir yeri olan Hirsch Kupfer ve Messingwerke şirketindeki çalışmalarında devam etti. Konut krizi nedeniyle kitlesel konut üretimi konusuyla ilgilenmeye başlayan şirket, bunun için bünyesinde özel bir birim kurmuş, Friedrich Förster ve Robert Krafft tarafından taşınabilir, yalıtımlı bakır panel duvarlardan oluşan prefabrik bakır evler geliştirilerek patentleri 1930 yılında alınmıştı. 1930'da burada çalışmaya başlayan Gropius prototipleri "sökülebilir" ve "büyüyen" ev fikirleri doğrultusunda geliştirdi. 1932'de Berlin'de "Güneş, Hava ve Barınma" sloganı ile düzenlenen İkinci Alman Yapı Fuarı'nda Gropius'un prototiplerden iki tanesi (L-1 ve L-2) yer aldı (Şekil 5). Bu evlerde Gropius'un günümüzde önemi artan "yapı bozumu" kavramını tasarım ile bütünleştirme, geliştirme çabası açıkça görülmektedir. Konstrüksiyon, herhangi bir ek bağlantı olmaksızın tek bir duvar elemanının sabitlendiği ahşap bir çerçeveden oluşuyordu. Duvar elemanı dört katmanlı bir yapıdan oluşuyordu: dışta bakır levhalar ve 
içte ince oluklu alüminyum levha. Bu levhalar içindeki boşluk, bitümlü karton üzerine iki alüminyum levha ve arasında üç hava katmanı oluşturur. Elemanlar daha basit ve daha etkili bir bağlantı mekanizması ile birleştirildi. Böylece bağlantıların sızdırmazlığı sağlanmaya çalışıldı (Kunkel, 2006; Tomlow, 2003; Prochiner, 2006).

Gropius'un kariyeri Bauhaus'un 1933'te kapatılması ve siyasi ve sosyal arka planıyla bağlantılı olarak, 1934 'te İngiltere'ye ardından 1937 'de ABD'ye göçünden sonra yeni bir yola girdi. 1937-1941 yılları arasında Marcel Breuer'le ortak çalışmalar yaptı (Uzun, 2019). İki mimar New York Dünya Fuarı (1939) için Pensilvanya Pavyonu başta olmak üzere birçok konut binası tasarladı (Tökmeci, 2013). Amerika'daki yıllarında Gropius, inşaat endüstrisi üyeleri ve prefabrikasyona dayalı inşaat endüstrilerinin yöneticileri ile sık sık görüşmeler yaparak, ülke çapında prefabrikasyona dayalı bina sistemi geliştirmek için mimarlar ve konut pazarlama şirketlerinin ortaklığı ile enstitüler kurulması gerektiğini ısrarla vurgulamaktaydı. Böylece çok sayıda rakip inşaat firmalarının prefabrike yapı bileşenlerini standart boyutlarda üretmek için uzlaşmaya varmasının, mimarlar için birbirinin yerine geçebilecek bileşen parçalarını kullanarak özgün konut binaları gerçekleştirme fırsatı yaratacağını savunuyordu (Jones, 2017). Bu idealini Otto Hetzer ile modern ahşap konstrüksiyonun iki inşaat öncüsünden biri olarak tarihe geçen Wachsmann ile yapacağı ortaklıkta gerçekleştirmeye çalışacaktı (Lennartz ve Jacob-Freitag, 2015). Wachsmann, ahşap yapı şirketi Christof ve Unmäck'ta Amerikan Balon ve Platform Çerçeve sistemlerini Alman gereksinimlerine uyarlamak için yeni patentler üzerinde çalıştıktan ve İkinci Dünya Savaşı'nda İtalya ve Fransa'daki sürgün yıllarından sonra, 1941'de Gropius'un yardımı ile ABD'ye gittiğinde yanında iki tane yenilikçi çizim vardı. Bunlardan biri çelik boru yapı sistemi tasarımı olan Mobil Hangar (Mobilar Hangar) diğeri ise; üç boyutlu modüler bir ızgaraya yerleşen panel yapı sistemiydi. İki mimar bu sistemler üzerinde çalışmaya başladı. Harvard Üniversitesi Tasarım Enstitüsü Dekanı Joseph Hudnut, tamamlanan çalışmayı ilk görenlerden biri olmuş ve Paketlenmiş Ev (Packaged House) (Şekil 6c) adını önermişti. Bu sistemin benzerlerinden farkı modülasyon, montaj ve inşaat sistemi kavramlarının eşdeğer önemde dikkate alan çözümler içermesiydi. Wachsmann'ın metrik sisteme göre hazırlanmış çizimlerinin, inçlere uyarlanması ise Gropius'un katkısı ile gerçekleşti. Amaç ABD'deki ticari ürünlerin ve üretim sistemlerinin tasarlanan sistemle bir çatışma yaşamasını önlemekti (Şekil 6.a). Böylece 1931'de Gropius'un bakır evlerde denediği teori, Paketlenmiş Ev projesinde kısmen uygulamaya geçti. Wachsmann panel modülleri ile bağlantı modüllerinin birbirine kolay entegre edilmesi, dört yönde duvar düzenlenme imkanının modüler koordinasyon ile sağlanması için panel boyutları ile bağlantı modüllerinin geometrik biçimlerinin tasarımına odaklandı. Paketlenmiş ev sistemin en büyük yeniliği şüphesiz kancalı bağlantı elemanları idi (Şekil 6b-c). Çünkü yapısal dikmeler olmadan kendi kendini destekleyen panellerden oluşan modüler sistemler zaten biliniyor ve uygulanıyordu. Gropius ve Wachsmann modüler ahşap çerçeve paneller ve bağlantılar üzerinde kapsamlı bir araştırma yaptı. Bu proje, bireysel olarak kolayca inşa edilebilir, tüketici ürünü olarak standartlaşmış, sanayileşmiş ve alternatif planlamalara imkân tanıyacak esnek bir sistem ortaya çıkarmayı amaçladığından bağlantılarda bu esnekliğe imkân tanıyacak yeni bileşenlerle oluşturulması hedeflenmişti. Böylece $X$ şeklinde kesitleri olan profiller üzerinde çalışıldı. Modüler panellerin kenarlarında 45 derece pahlı yüzeyler oluşturularak bağlantı profillerine kolayca bağlanması sağlandı (Deamer, 2000; Seelow, 2018; Rodríguez ve Montrabal, 2011; Imperiale, 2012). Burkhart ve Arieff (2002)'a göre, ev için gerekli olan gerekli duyusal mekânsal niteliklerin, prefabrike ve önceden tanımlanmış bir sistem olarak inşaatın teknik meselelerinin gölgesinde kaldığı görüşü yer alır. Geleneksel yerinde yapım binaların, yüksek hassasiyetli fabrika montajı gerektiren yapı parçalarına dönüşümü ve prefabrikasyonu, geleneksel inşaat kadar maliyetli, bağlantı ve tolerans zorluklarına neden olmuştur (Frier vd., 2008). Bunlara rağmen, özellikle Gropius ve Wachsmann'ın evrensel eklemi tekrarlanabilir ve benzersiz bir inovasyondur. Çünkü herhangi bir kişinin bile sistemi kolayca kurmasına imkân tanıyan, esnek, özgün ve sürdürülebilir bir yenilik içerir. $\mathrm{Bu}$ deneysel proje aynı zamanda fabrika iş̧̧iliğinin ekonomik ve kültürel olarak değerli hale getirilmesinde gösterilen ileri çabaları da temsil eden inovasyon değerlerini de inşaat sektörüne kazandırmıştır. 

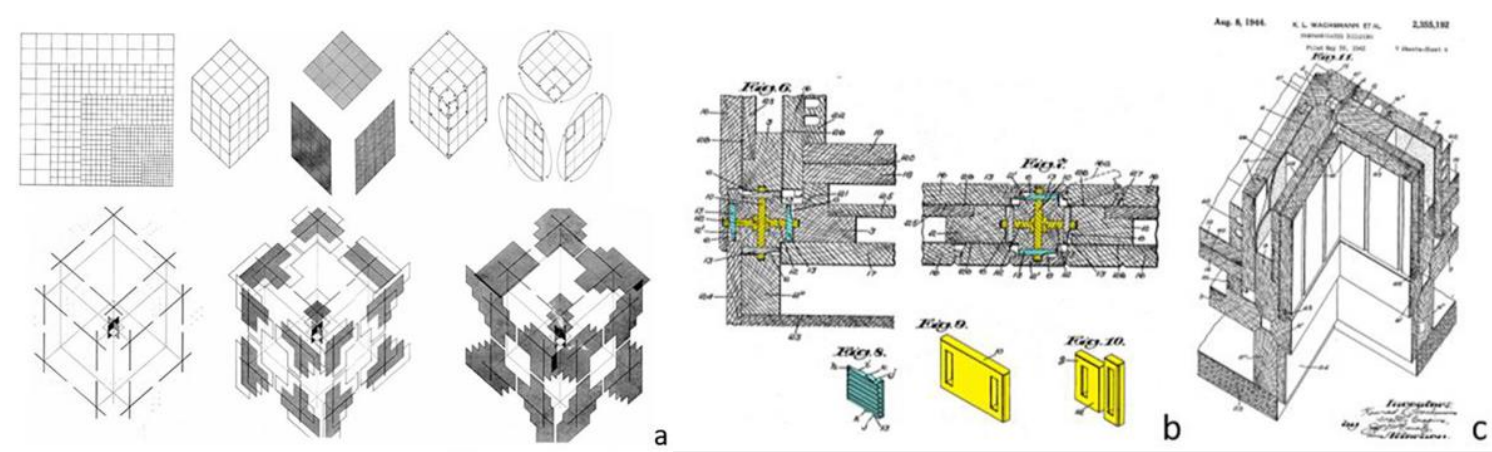

Şekil 6. Konrad Wachsmann ve Walter Gropius, Paketlenmiş Ev, 1941, a. Sistemin üç boyutlu anlatımı (Sabatto, 2015, s.142), b. 12 doğrultuda büyüyebilen bağlantı noktası, c. Kesit-perspektif (Wachsmann ve Gropius, 1944)

Gropius'un Paketlenmiş Ev projesine katkısı daha çok plan tipleri geliştirerek olmuştur. Temel bir plandan yola çıkarak, farklı plan tiplerinin paketlenmiş ev sistemi ile uygulanabilirliğini göstermeyi hedeflemiş, mimaride esneklik kavramının tasarım alternatifleri üzerinden test edilmesine yönelik bir çalışma modelinin hayata geçmesinde rol oynamıştır. Binaların yere bağlı olmama iddiaları pazarlama güçlüklerini beraberinde getirdiğinden sisteminin üretimi ve pazarlanması için kurulan General Panel Corporation şirketi birkaç prototip ve yaklaşık 150-200 birim inşa ettikten sonra devlet desteği yeterli gelmeyince iflas etmiştir. Yetersiz fonlar sistemin doğru şekilde tanıtılmasına engel olmuştur (Seelow, 2018; Rodríguez ve Montrabal, 2011; Herbert, 1984). Bu noktada pazarlanabilme yeteneğinin inovasyon değeri belirlemede önemli bir yeri olduğuna vurgu yapmak gerekir. İnovasyon tasarım, bilim ve teknoloji etkinliği alanlarını kapsayan bir süreçtir. Fikrin bir yarara dönüşmesi ve bu yararın pazarlanabilir, somut bir çıktı haline gelmesi inovasyonların en önemli özelliğidir (Kavak, 2009). Bu bağlamda mimari veya yapısal inovasyonların pazarlanabilir olması ve tasarımda pazarlama stratejisi girdisinin kullanılmış olması da değerlendirilmesi gereken bir unsurdur. Gropius Paketlenmiş ev projesinde esnek tasarım ve uyarlanma imkânı sunan teknolojik ve sistemsel yeniliği pazarlama için öncelik olarak belirlemişti. Tanınmış kişiliği ve bağlantıları nedeniyle projede halkla ilişkiler ve tanıtım görevini üstlendi. Finansman sağlamak için çalıştı. Halka açık gösteriler düzenleyerek sistemin yaygınlaşmasını teşvik etmeye çabaladı. Ancak, Gropius'un girişimci yapısına rağmen Wachsmann'ın mükemmeliyetçiliği ve detaycılığının projenin gelişmesini kısmen engellemiştir. Bütün bunlara rağmen, benzersiz ve esnek dikme profillerinin o yıllarda yeterli ilgiyi görememiş olması bu projedeki inovasyonun değerini düşürmez. Daha önce üzerinde durulduğu üzere inovasyonda uzun vadedeki etkiler ve çıktılar ile sektördeki gelişmelere katkısının göz ardı edilmemesi gerekir.

Paketlenmiş Ev girişiminin sonuçlanmasının ardından Gropius genç nesil mimarlar ile bir araya gelerek TAC (The Architects Collaborative) Mimarlık Grubu ile mesleki çalışmalarına devam etti. Bu grupla beraber pek çok büyük ve önemli projeye imza attı. Gropius'un modern mimarinin gelişmesi için önemine inandığı ekip çalışması ve disiplinler arası etkileşimin etkileri bu projelerde de görülmektedir (Tökmeci, 2013).

\section{Tartışma ve Sonuç}

Çalışmaları ve yayınladığı metinler değerlendirildiğinde Gropius'un inovasyon için kaynak motivasyonları aşağıdaki şekilde değerlendirilmiştir.

- Sanayi, teknoloji, üretim sistemleri ve yaratıcılıkla beslenen ilham.

- Devrimci düşünce yapısı, yetenek ve yorumlama becerisi ile ön plana çıkan iç görü.

- Teknik, teknoloji ve geleceğe duyulan merak.

- Farklılaşma ve ilerleme arzusu ile gelecek idealini şekillendiren hayal gücü.

- Gerçekçi, ilerici, rasyonel düşünce yapısının oluşturduğu mantık.

- Çeşitlilik, esneklik, değişebilirlik, uyarlanabilirlik, yapılabilirlik hedefleyen tasarımda özgünlük.

- İstikrarlı gelişme, çalışkanlık, üretme ve sebatkarlıkla biçimlenen irade.

- Girişimci ve paylaşımcı karakter ile ortaya çıkan ifade gücü. 
- Özgür düşünce, meslek etiği ve görev bilinci ile seçim yapma.

Mimarın bu motivasyon kaynakları sistem kurucu sıfatını da fazlasıyla hak ettiğini gösteriyor. Amacı doğrudan inovasyon değeri oluşturmak olmasa da ona göre mimar "biyolojik, sosyal, teknik ve yaratıcı tüm sorunları bir araya getirerek birleştirmesi gereken bir organizatördür". Asıl amaç tasarımda özgünlükten ödün vermeden gelişmeye açık proje hedeflerine ulaşmaktır. Günümüzde inovasyonun temel kaynaklarından biri kabul edilen proje, farklı alanlarda uzmanlığa sahip aktörlerin bilgilerini belirli sorunları çözmek için kullanabilecekleri yaratıcı bir ortamdır. Inşaat sektöründe geliştirilen yaklaşımların inovasyon olarak değerlendirilebilmesi için çözümler içermesi, bu çözümlerin tarif edilmiş hatta kodlanmış olması ve gelecekte kullanılabilecek fikirleri içermesi gerekir (Davis vd., 2016; Slaughter, 1993; Winch, 1998). Öte yandan inşaat sektöründeki aktörlerin tasarım yaklaşımlarındaki belirsizlikler bina üretiminde inovasyon değeri elde etmeyi zorlaştırmaktadır. Bunun en güçlü nedeni, tasarım düşüncesine ilişkin mevcut teorik bilgi ile pratik uygulaması arasındaki önemli boşluk olarak görülür (Kleinsmann ve diğerleri, 2017). Endüstriyel ilkelere göre tasarım ve inşa süreçlerinin rasyonalizasyonunun öncülleri ve tahmincileri olarak kabul edilen Gropius ve döneminin ilerici meslektaşları, mimaride pek çok müteakip sanayileşme çabalarının da temelini attılar. Bu temeli oluştururken bilgiyi üretme ve bilgiyi uygulamaya dönüştürme ilkeleri ile hareket etmişlerdir. Özellikle Gropius, mimarinin rasyonalizasyonu için iki farklı kavramı keşfetmekle kalmamış, bunları uygulayarak sonuçlarını inşaat inovasyonu literatürüne kazandırmıştır. Böylece daha sonraki inovasyonlar için zemin hazırlamıştır. Teknolojinin genel yaşam koşullarını iyileştirme yeteneğine inanan ve inşaat inovasyonunda sürdürülebilirlik sağlamaya çalışan Gropius, bu kavramları bir dizi proje ve deneysel çalışmada çoğu kez kanıtlayıcı ve öğretici tarzda formüle etmiştir. Ford montaj hattı mantığından farklı olarak, farklı bileşen türlerine dayalı ve farklı endüstriyel biçimlere bağlı prefabrike yapı üretim sistemlerine yönelik çalışmaları bugünkü "açık yapı" (open building) ve "kitlesel özel üretim" (mass customization) kavramlarının ilk uygulama örneklerini de barındırır. Gropius endüstriyel üretim yolu ile esnekliği sağlama ve seri üretim yoluyla maliyeti düşürme hedefine istediği seviyede ulaşamamış olsa da bu deneyimler inşaat sektöründe sürdürülebilir inovasyonları başlatmıştır. Örneğin, Richard Buckminster Fuller (Dymaxion evi), Fritz Haller (USM Haller Mini, Midi ve Maxi), Jean Prouvé (Maison Tropicale) gibi tasarımcıların, esnek yapım kiti ilkesi üzerinde çalışmaya ve özgün tasarımları ile prefabrikasyona inovasyon değeri kazandıracak projeleri ortaya koymaya ısrarla devam ettiler (Seelow, 2018). Bazı çevrelerde toplumsal, ekonomik ve sosyal nedenlerle Modernizm'in öncü mimarlarının prefabrikasyona yönelik bu çalışmaları başarısızlık olarak değerlendirilmektedir. Ancak bu değerlendirmeye katılmak, söz konusu mimarların kolaycılıktan ve tekrardan kaçınarak yenilik yapma ve ilerleme için bütün riskleri göze alarak çalışma iradelerini görmezden gelmek olur. Mimarlığın bilgiyi kullanma ve üretmeye dayalı bir alan olduğu düşünüldüğünde, yaratıcı ve devrimci iradesi bilgiyi üreten, uygulamaya dönüştüren ve gelecekteki ilerlemelerin yolunu açan bu öncülerin entelektüel ve teknolojik inovasyonları yarattığını söylemek mümkündür.

Mimarların yalnızca tasarımın temel gereksinimlerini karşılayan geçerli yaklaşımlara saygılı davranma ihtiyacıyla değil, aynı zamanda birçok konuyu, sorunu gerçekten kavrama ihtiyacıyla da yüzleşir. Mimari karmaşık bir problemin çözülmesi için mimarın kullandığı iki tür bilgi vardır. Resmi (açık) bilgi, tasarımın standartlarından, teknik şart ve standartlardan kaynaklanan, aynı zamanda tasarım paradigmalarını da içeren bilgilerdir. Örtük (zımni) bilgi ise, bireysel yaratıcılık ile ilgilidir. Her iki bilgi türü de inovasyon yaratımında mimarın entelektüel ve yaratıcı sermayesidir (Bonenberg ve Kapliński, 2017). Örneğin, Gropius tarafından yaratılan tüm değerlere akıl, aydınlanma ve yenilikçi düşünce yaklaşımı rehberlik eder. Amacı, sanatsal iradeyi kısıtladığı düşünülen teknoloji ve ekonomik sınırlamaların üstesinden yine "yaratıcı irade" ile gelmektir (Röder ve Elliott, 1998). Bu noktada inovasyon değeri yaratmada tasarım düşüncesinin rolünü de sorgulamak gerekir. Tasarımcının proje hedefine yönelik karşılaştığı zorluklar, tasarımcının inovasyon vizyonunu ortaya çıkaran en önemli faktördür. Bu zorluklarla yüzleşen mimar çözümlerini prototipler ile test eder. Gropius ve diğer öncüllerin "prototip" olmaktan öteye gidemedikleri için bazı çevrelerce değersizleştirilen projeleri, bu bakış açısı ile tam tersine birer inovasyon değeri veya girdisi olarak yorumlanabilir. Kleinsmann vd. (2017) inovasyona yönelik tasarım düşüncesine ilişkin uygulamaların dört ana başlıkta toplandığına ve 
her birinde prototip üretmenin önemine vurgu yapar. Bunlar değer odaklı inovasyon, deneyim odaklı inovasyon, amaca yönelik inovasyon ve vizyon odaklı inovasyondur. Buna göre, tasarım odaklı düşünme, yenilikçinin projeye yönelik amacına, yenilik konusundaki vizyonuna ve karşılaştı̆̆ı ana zorluğa bağlıdır. Değer odakı inovasyonda, yenilikçiler prototiplemeyi temel olarak farklı paydaşların çeşitli bilgi tabanlarının sentezi için kullanırlar. Prototipler, inovasyon projesinin teknik karmaşıklığı hakkında ortak bir anlayış oluşturmak ve paydaşlar hakkında zımni varsayımları ortaya çıkarmak için kullanılır. Deneyime dayalı inovasyonda, özellikle son kullanıcı için neyin değer yaratacağııın belirlendiği keşif aşamasında, kullanıcılarla iş birliğine dayalı prototip oluşturmaya vurgu yapılmaktadır. Mimari tasarımda da yenilikçi yaklaşımlar içeren projeler, prototipler oluşturularak, tüm paydaşların katıımı ile teknik karmaşıklıkların çözümü için kullanılırlar. Amaca yönelik inovasyonda, yenilikçiler fikirleri kavramlara dönüştürmek için prototipler kullanır. Bu kavramlar, çok disiplinli ekipte ortak bir anlayışın oluşturulmasını kolaylaştırır. Vizyona dayalı inovasyonda ise yenilikçiler, paydaşlarla bir diyalog başlatmak ve oluşturulan vizyonu test etmek için prototipler kullanır. İnovasyon faaliyetleri, yenilikçilerin tüm inovasyon süreçlerinin önemli yönlerini ele almak için tasarım düşüncesini kullandıklarını açıkça göstermektedir.

Bu çalışmada incelenen literatüre dayanarak inovasyon süreci üç temel aşamaya ayrılmış, Bonenberg ve Kapliński (2017), Davis (2016), Godin (2008), Kleinsmann ve diğerleri (2017), Lundvall (2007), Manley (2008), Moe ve Smith (2012), Scruton (2013), Smith ve Quale (2017), Tatum (1989), Xue vd. (2014) ve Wylant (2008)'den yorumlanarak bir süreç grafiği hazırlanmıştır (Şekil 7). Bunlar "inovasyon girişi", "inovasyon eylemi/işlemi" ve "inovasyon çıktısıdır". Sürecin girdileri ise "motivasyon kaynağı", "inovasyon düşüncesine etki eden etmenler", "tasarımda inovasyon düşüncesi" ve "inovasyon türü"dür. Mimar inovasyon girişi için gerekli olan kaynakları belirleme, temin etme ve yönetmekle sorumludur. Diğer taraftan motivasyon kaynakları yanında mevcut veya yeni araçları, yöntemleri teknik, teknoloji, ekonomi ve mantık çerçevesinde kullanarak sürecin proje aşamalarındaki girdileri de belirler. Bu süreçte sistem düşüncesi yeteneğini kullanır. İnovasyonun yaratılmasındaki aşamalar fikrin geliştirilmesi, tasarım, dönüştürme, yayılım olarak devam eder. Bu aşamalar fikri ortaya koyma ve tasarım aşamalarında İnovasyon düşüncesini yönlendiren etmenler ekonomi, tasarım problemi veya yapım stratejisi olabilir. Örneğin prefabrikasyonda yirminci yüzyılın ortalarına kadar, yapıların teknik verimliliğini artırma ya da maliyetlerini düşürme çabasının ön planda tutulduğu uygulamalar inovasyonu teşvik etmemiştir (Bowley, 1966; Manseau, 2018). Aşina olunan materyal, yöntem veya kaynakların çözüme ulaşmada yetersiz kalması, yapılarda büyük yeniliklerin gelişimini teşvik etmekle birlikte, inovasyonları teşvik eden nedenler genellikle bir tasarım problemi veya müşteri taleplerini karşılamak için yapım yöntemlerine teknolojinin entegrasyonu olarak karşımıza çıkar. 


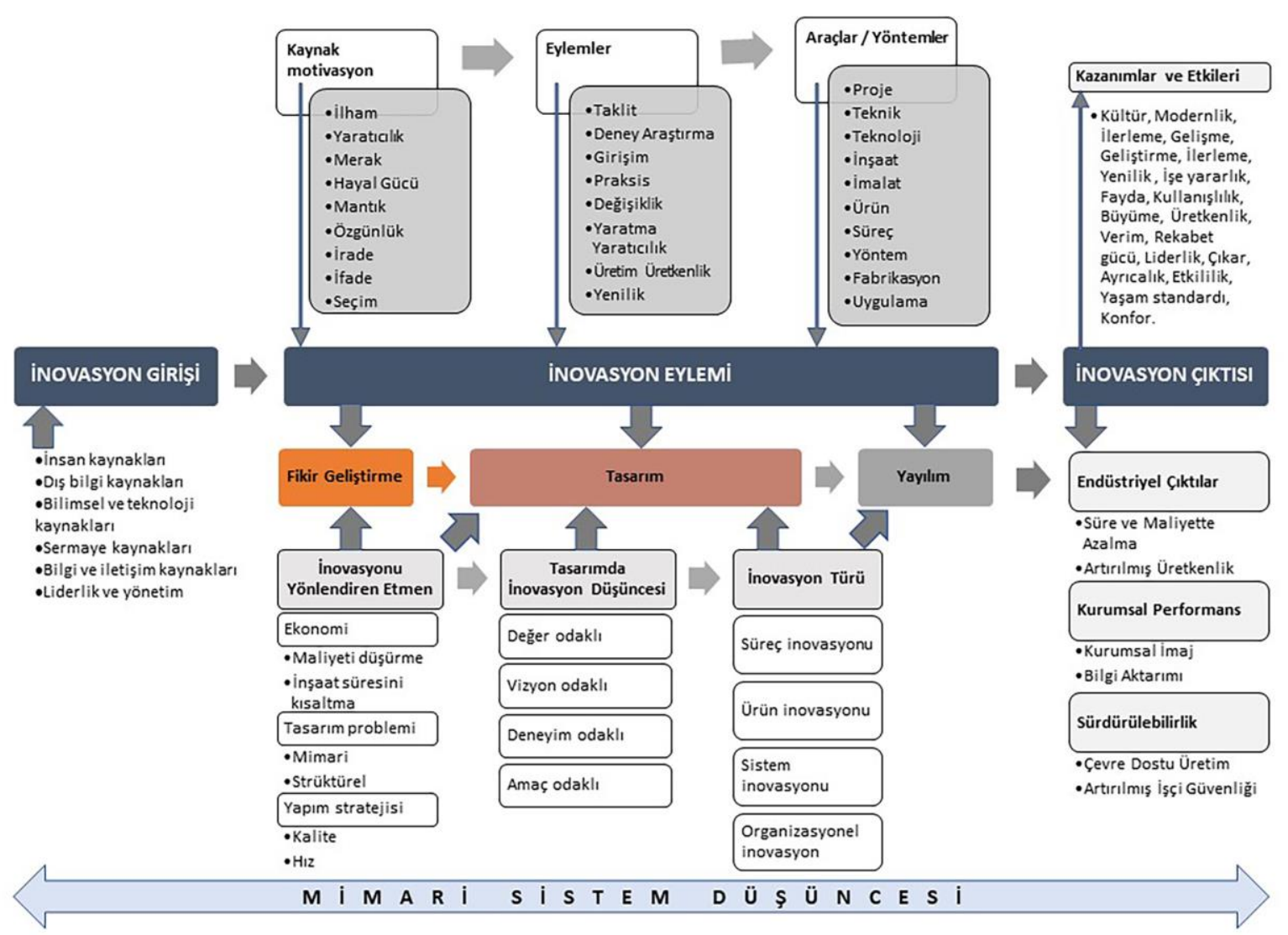

Şekil 7. Yapı üretiminde mimarın rol aldığı, yönlendirdiği ve etkilediği inovasyon süreçleri

Sonuç olarak, inovasyonu başlatan temel tetikleyici yenilikçi ve onun motivasyon kaynaklarıdır. Tasarıma dayalı ürünü gerçekleştirme faaliyeti olan mimarlık ve yapı üretimi söz konusu olduğunda bu görev mimardadır. Mimarın deneyimi, vizyonu ve sanat, estetik ve teknolojiyi tasarım düşüncesi ile yorumlama becerisi inovasyon değerinin ortaya çıkmasında önemli faktörlerdir. Hatta bu niteliklerin üst düzeyde varlığı, mimari ürünün başlı başına bir inovasyon olarak ortaya çıkmasına neden olur. Bu nedenle mimarlıkta inovasyon değeri, teknoloji dar alanı içerisinde değerlendirilemez. Tasarımcı kimliği ile mimarın formu oluşturmak üzere, en güçlü yönleri ile uzlaşarak her türlü teknolojiyi yeniden şekillendirmesi inovasyonların sürdürülebilirliğini sağlar.

\section{Teşekkür ve Bilgi Notu}

Makalede, ulusal ve uluslararası araştırma ve yayın etiğine uyulmuştur. Çalışmada etik kurul izni gerekmemiştir.

\section{Kaynaklar}

Abrahamson, E. (1996). Management fashion. Academy of Management Review, 21(1), 254-285.

Alvis, J. A. M. (2017). Through a Technique of Building, Icon, 23, 83-112.

Anlage Katalog Kupferhäuser, katalog no:12. Erişim adresi (10.01.2021): https://depositonce.tuberlin.de/bitstream/11303/3743/3/Dokument_16.pdf.

Arieff, A. ve Burkhart, B. (2002). Prefab, 1st edition, Layton: Gibbs Smith, 24-25.

Bayer, H., Gropius, W., ve Gropius, I. (Ed.). (1938). Bauhaus, 1919-1928, CT Branford Company, 17, 110-111.

Bonenberg, W. ve Kapliński, O. (2017). Knowledge is the key to innovation in architectural design, Procedia Engineering, 208, 2-7. doi: https://doi.org/10.1016/j.proeng.2017.11.013.

Bowley, M. (1966). The British building industry: Four studies in response and resistance to change, 1st edition, Cambridge: Cambridge University Press, 169-170. 
Brookes, A. J. ve Poole, D. (2012). Innovation in Architecture: A Path to the Future, 1st edition, New York \& London: Taylor \& Francis, 1-16.

Burkhart, B. ve Arieff, A. (2002). Prefab, 1st edition, Layton: Gibbs Smith, 24-25.

Carsten Janssen / cc-by-sa-2.0-de (2021). File: Fagus Gropius Hauptgebaeude 200705 wiki front.jpg. (2021, January 31). Wikimedia Commons, the free media repository. Erişim adresi (03.05.2021):

https://commons.wikimedia.org/w/index.php?title=File:Fagus_Gropius_Hauptgebaeude_2007 05_wiki_front.jpg\&oldid=529526621.

Carvalho, O. (2007). The Revolutionary Mentality, Çev. Tiago Tondineli, A mentalidade revolucionária, Diário do Comércio. Erişim adresi (13.12.2020): http://againstred.blogspot.com/2007/09/revolutionary-mentality-by-olavo-de.html.

Davis, Gajendran, T. Vaughan, J. ve Owi, T. (2016). Assessing construction innovation: theoretical and practical perspectives, Construction Economics and Building, 16(3), 104-115. doi:10.5130/AJCEB.v16i3.5178.

Deamer, (2000). Detail: The Subject of the Object, Praxis, 1(1), 108-115.

Dosi, G. (1988). Sources, Procedures, and Microeconomic Effects of Innovation, Journal of Economic Literature, 26(3), 1120-1171.

Freeman, C. ve Soete, L. (1997). The Economics of Industrial Innovation, 3rd edition, Oxon: Routledge, 197.

Frier, M. Fisker, A. M. ve Kirkegaard, H. (2010). Prefab-Interiority: Design Principles for a Sensuous Prefab Practice, Design Principles and Practice: An International Journal, 4(2),415-426. Erişim adresi (15.01.2021): http://ijg.cgpublisher.com/product/pub.154/prod.390.

Godin, B. (2008). Innovation: the History of a Category. Project on the Intellectual History of Innovation, Working Paper, Montreal: INRS, 1-67. Erişim adresi (12.11.2020): http://www.csiic.ca/PDF/IntellectualNo1.pdf.

Gropius, W. (1927). Wege zur fabrikatorischen Hausherstellung, In Bau und Wohnung, Deutscher Werkbund, Stuttgart: Akad. Verlag Dr. Fr. Wedekind \& Co., 61.

Gropius, W. (1930). Bauhausbauten Dessau, Walter Gropius \& László Moholy-Nagy (Ed.). Bauhausbücher 12, Munich: A. Langen. 161.

Herbert, G. (1984). The Dream of the Factory-Made House: Walter Gropius and Konrad Wachsmann, 1st edition, Cambridge: Mit Press.

Hoffa, H. (1961). Walter Gropius Innovator, Art Education, 14(1), 22-28.

Imperiale, A. (2012). An American Wartime Dream: The Packaged House System of Konrad Wachsmann and Walter Gropius, 2012 ACSA Fall Conference: OFFSITE, Philadelphia: Temple University, Modular Building Institute, 39-43. Erişim adresi (05.11.2020): https://www.acsaarch.org/proceedings/

Fall\%20Conference\%20Proceedings/ACSA.FALL.12/ACSA.FALL.12.8.pdf.

Jones, D. E. (2017). Walter Gropius and the (Not So) Infinite Possibilities of Prefabrication. Erişim adresi (24.11.2020): https://aiacalifornia.org/walter-gropius-and-prefab/

Jönsson, R. (2013). Fred Forbat and the History of Functionalism, Nordic Journal of Architectural Research, 16(4), 79-85. Erişim adresi (05.01.2021): http://arkitekturforskning.net/na/article/download/300/260.

Kamien, M. I. ve Schwartz, N. L. (1982). Market Structure and Innovation, Cambridge: Cambridge University Press, 2. 
Kavak, Ç. (2009). Bilgi Ekonomisinde Inovasyon Kavramı ve Temel Göstergeleri, Akademik Bilişim'09XI. Akademik Bilişim Konferansı, 11-13 Şubat, Şanlıurfa: Harran Üniversitesi, 617-628. Erişim adresi (16.01.2021): https://ab.org.tr/ab09/kitap/kavak_inovasyon_AB09.pdf.

Kinnunen, J. (1996). Gabriel Tarde as a Founding Father of Innovation Diffusion Research, Acta Sociologica, 39(4), 431-442. Erişim adresi (05.01.2021): https://www.jstor.org/stable/4194846.

Kleinsmann, M. Valkenburg, R. ve Sluijs, J. (2017). Capturing the Value of Design Thinking in Different Innovation Practices, International Journal of Design, 11(2), 25-40.

Koeper, H. F. (2020). Walter Gropius, Encyclopedia Britannica, Erişim adresi (03.01.2021): https://www.britannica.com/biography/Walter-Gropius.

Kunkel, U. (2006). Kupferhäuser der Hirsch Kupfer- und Messingwerke aus Eberswalde-Finow, 1930 33 ... in die Jahre gekommen, $\mathrm{db}$ deutsche bauzeitung, Erişim adresi (03.01.2021): https://www.db-bauzeitung.de/db-themen/schwerpunkt/in-die-jahre-gekommen-25/.

Lennartz, M. W. ve Jacob-Freitag, (2015). New Architecture in Wood: Forms and Structures, Birkhäuser, 8.

Loureiro, F. (2014). The Revolutionary Mind of Walter Gropius: Architectural Utopias for the Machine Age, Utopian Studies, 25(1), 174-193. doi:10.5325/utopianstudies.25.1.0174.

Lundvall, B. A. (2007). National Innovation Systems: Analytical Concept and Development Tool, Industry and Innovation, 14(1), 95-119. doi:10.1080/13662710601130863.

Manley, K. (2008). Against The Odds: Small Firms in Australia Successfully Introducing New Technology on Construction Projects, Research Policy, 37(10), 1751-1764. doi:10.1016/j.respol.2008.07.013.

Manseau, A. (2005). Building Tomorrow: Innovation in Construction and Engineering, Kindle Edition, Taylor \& Francis, 409-411.

Meyrick, J. (2016). Exactly what is innovative about the word 'innovation'?, Erişim adresi (08.12.2020): $\quad$ https://theconversation.com/exactly-what-is-innovative-about-the-wordinnovation-58720.

Miozzo, M. ve Dewick, (2004). Innovation in Construction: A European Analysis, Edward Elgar Publishing, 13-15.

Moe, K. ve Smith, R. (2012). Introduction: systems, technics, and society, Building Systems: Design Technology and Society, Kiel Moe \& Ryan E. Smith (Ed.), New York: Routledge, 1-9.

Mumford, L. (1934). Technics and Civilization, San Diego: Hartcourt Brace and Co., 13-20.

Nerdinger, W. (1988). Walter Gropius: opera completa, Segrate: Edizioni Electa, 70.

Nierendorf, K., (1923). Staatliches Bauhaus Weimar 1919-1923, Weimar and Munich: Bauhausverlag. 169-170.

OECD. (2005). Oslo Manual: Guidelines for Collecting and Interpreting Innovation Data, 3. Basım (Dijital kopya), Paris: OECD Publishing, Erişim adresi (05.11.2020): https://www.oecdilibrary.org/docserver/9789264013100en.pdf?expires=1610794466\&id=id\&accname=guest\&c hecksum=0150B3015F3A0406CF41FC99219734C8.

Ogburn, W. F. (1941). National Policy and Technology, Technology And Society: The Influences of Machines in The United States, Rosen M. \& Rosen L. (Ed.), New York: Macmillan Co., 3-29.

Piroozfar, P. ve Farr, E. R. (2013). Evolution of Nontraditional Methods of Construction: 21st Century Pragmatic Viewpoint, Journal of Architectural Engineering, 19(2), 119-133. doi:10.1061/(ASCE)AE.1943-5568.0000078.

Prochiner, F. (2006). Homes 24 (Doktorarbeit). Münih: Technische Universität München, Fakultät für Architektur, 25. 
Rodríguez, L. F. ve Monrabal, C. (2011). El General Panel System de Konrad Wachsmann y Walter Gropius, 1941, Actas del Séptimo Congreso Nacional de Historia de la Construcción, Santiago, 375-385, Erişim adresi https://dialnet.unirioja.es/servlet/articulo?codigo=4133200.

(12.12.2020):

Rogers, E. M. (1983). Diffusion of Innovations, 3rd Edition, New York: Free Press.

Röder, S., ve Elliott, F. (1998). Moderne Baukunst 1900-14: The Architectural Collection of the Deutscher Werkbund. The Journal of the Decorative Arts Society 1850-the Present, (22), 4-17. Erişim adresi (26.12.2020): http://www.jstor.org/stable/41809268.

Rupnik, I. (2012). Industrialized Housing Delivery and The Role of the Architect, Kiel Moe \& Ryan E. Smith (Ed.), Building Systems: Design Technology and Society (86-103). New York: Routledge.

Sabatto, S. (2015). L'espace dans l'iconoclaste distribution des contraintes et des souhaits : Modèles, photos et dessins dans la conception des systèmes constructifs de la Guerre Froide. Carte Semiotiche / Images qui font signe. Modes et pratiques de représentation diagrammatique dans les images informationnelles, 142. Erişim adresi (19.01.2021): https://www.researchgate.net/publication/321211317_L'espace_dans_l'iconoclaste_distributi on_des_contraintes_et_des_souhaits_Modeles_photos_et_dessins_dans_la_conception_des_ systemes_constructifs_de_la_Guerre_Froide.

Schumpeter, J. A. (1939). Business Cycles: A Theoretical, Historical, and Statistical Analysis of the Capitalist Process, New York: McGraw-Hill, 84-85.

Scruton, R. (2013). The Aesthetics of Architecture, New Jersey: Princeton University Press, 85-87.

Seelow, A. M. (2018). The Construction Kit and the Assembly Line-Walter Gropius' Concepts for Rationalizing Architecture, In Arts, 7(4), 95. doi:10.3390/arts7040095.

Slaughter, E. (1993). Builders as Sources of Construction Innovation, Journal of Construction Engineering and Management, 119(3), 532-549. doi:10.1061/(ASCE)07339364(1993)119:3(532).

Smith, R. E. ve Quale, J. D. (Ed.) (2017). Offsite architecture: constructing the future, 1st Edition, Londra: Routledge.

Tatum, C. B. (1989). Organizing to Increase Innovation in Construction Firms, Journal of Construction Engineering and Management, 115 (4), 602-617. doi:10.1061/(ASCE)07339364(1989)115:4(602).

Tomlow, J. (2003). Industrialized log building by the Christoph \& Unmack in Saxony (1907-1940), Proceedings of the First International Congress on Construction History, 20-24 January, Madrid: Instituto Juan de Herrera, 1989-1999, Erişim adresi (05.11.2020): http://www.sedhc.es/biblioteca/actas/CIHC1_186_

Tomlow\%20J.pdf.

Tökmeci, E. Ö. (2013). Mimarlıkta Rasyonellik, 1. Basım, İstanbul: Mimar Sinan Güzel Sanatlar Üniversitesi Yayınları, 85-86.

Uzun, T. (2019). Bauhaus Ekolü ve Kuramsal Arka Planı, Latif Gürkan Kaya (Ed.), Mimarlık Planlama ve Tasarım Alanında Yeni Ufuklar (411-488). Ankara: Gece Akademi. Erişim adresi (5.11.2020): https://www.gecekitapligi.com/Webkontrol/uploads/Fck/mimarlik_9.pdf.

Wachsmann, K. L., ve Gropius, W. (1944). U.S. Patent No. 2,355,192. Washington, DC: U.S. Patent and Trademark Office, Erişim adresi (19.01.2021): https://patentimages.storage.googleapis.com/20/0c/74/ 26583f61abd58b/US2355192-drawings-page-3.png.

Winch, G. (1998). Zephyrs of Creative Destruction: Understanding the Management of Innovation in Construction, Building Research and Information, 26(5), 268-279. doi: 10.1080/096132198369751. 
Wylant, B. (2008). Design Thinking and the Experience of Innovation, Design Issues, 24(2), 3-14. doi:10.1162/desi.2008.24.2.3.

Xue, X. Zhang, R. Yang, R. ve Dai, J. (2014). Innovation in Construction: A Critical Review and Future Research, International Journal of Innovation Science, 6(2), 111-126. doi:doi.org/10.1260/1757-2223.6.2.111. 